\title{
A New Gene (Prpi-2) for Intensified Anthocyanin Expression (IAE) Syndrome in Common Bean and a Reconciliation of Gene Symbols Used by Early Investigators for Purple Pod and IAE Syndrome
}

\author{
Mark J. Bassett \\ Horticultural Sciences Department, IFAS, University of Florida, Gainesville, FL 32611
}

\begin{abstract}
AdDitional INDEX WORDS. Phaseolus vulgaris, pleiotropy, epistasis, trigenic interactions
ABSTRACT. The inheritance of intensified anthocyanin expression (IAE) in a syndrome of plant organs of common bean (Phaseolus vulgaris L.) was investigated. A selection from accession line G07262, having white flowers with blue veins on the wing petals and a long, white micropyle stripe on black seedcoats, was used as the source of IAE syndrome. G07262 was crossed with three genetic tester stocks based on Florida dry bean line 5-593, which has the flower and seedcoat genotype $T P[C r] Z J G B V R k$. The tester stocks were 5-593 (black seed and bishops violet flowers), $t z$ bip bipunctata $\mathrm{BC}_{1}$ 5-593 (a partly colored seedcoat), and $v \mathrm{BC}_{2}$ 5-593 (mineral brown seedcoat and white flowers). Analysis of the $\mathrm{F}_{1}$ and $\mathrm{F}_{2}$ data from the test cross $\mathrm{G07262} \times t z$ bip bipunctata $\mathrm{BC}_{1}$ 5-593 demonstrated that 1) G07262 has genotype $t p^{\text {mic }}$ $V$; 2) genotype $t / t$ prevents expression of IAE syndrome by a dominant gene (Prpi-2) carried cryptically by G07262, i.e., $T /$ - is required for expression of the gene; and 3) $\operatorname{Prp}^{\mathrm{i}}-2$ may (preliminary data) express blue veins on white flowers with $t V$. From the cross with $v \mathrm{BC}_{2}$ 5-593, an $\mathrm{F}_{4}$ selection for white flowers with red banner back and mineral brown seedcoats (due to $v$ ) was made. When the $\mathbf{F}_{4}$ selection was crossed with 5-593, analysis of the $\mathrm{F}_{2}$ progeny demonstrated that G07262 carries a dominant gene for IAE syndrome, which expresses with $V /$ - but not with $v / v$. From the test cross 5-593 x G07262, a series of additional cycles of selection and test crosses (including the dark red kidney tester $c^{\mathrm{u}} b \boldsymbol{v} \boldsymbol{r k}^{\mathrm{d}}$ $\mathrm{BC}_{1}$ 5-593) were made, and two new two-colored seedcoat patterns were developed that have never been previously reported. In a test cross with one of them, $\mathrm{F}_{2}$ data demonstrated that the dominant gene for IAE syndrome from $\mathrm{G07262}$ is independent of the $C$ locus, and the gene symbol Prpi-2 is proposed for this IAE syndrome gene to distinguish it from the previously reported IAE syndrome gene $\left[c^{\mathrm{u}} \boldsymbol{P r} p^{\mathrm{i}}\right]$. A gene symbol reconciliation was made for all previous work with inheritance of IAE syndrome and purple pod genes without the syndrome.
\end{abstract}

The old literature relating to purple pods alone or the intensified anthocyanin expression (IAE) in a syndrome of plant organs (flower, pod, stem, and leaf) in common bean (Phaseolus vulgaris L.) was reviewed tersely by Prakken (1970). A more descriptive review of that literature and the gene effects is needed to prevent future investigators from making oversights of past work, as has happened several times in the past (described below). Shaw (1913) was the first to report a change in flower color that was correlated with a change in stem and leaf color, which he erroneously hypothesized was controlled by a single gene. The "crimson" (intense purple) flowers were associated with purple stems and leaves derived from 'Blue Pod Butter', whereas "waxy pink" (intense pink) flowers were associated with the absence of purple stems and leaves. Lamprecht (1935) assigned the gene symbol Nud to this hypothetical locus, which Nakayama (1964) and Lam-Sanchez and Vieira (1964) correctly described as the result of a two-gene interaction (described below). Lamprecht (1951) reported a two-gene interaction that expressed purple pods with Ro Pur, rose pods with Ro pur, and green pods with ro Pur/- or pur/pur. Lam-Sanchez and Vieira (1964) proposed a two-gene interaction for flower and pod color, viz., $R o V$ for violet flower and dark purple pod, ro $V$ for violet flower and yellow pod (with violet stripes), Ro $v$ for white flower and red pod, and ro $v$ for white flower and and yellow pod.

Received for publication 16 Dec. 2004. Accepted for publication 29 Jan. 2005. Fla. Agr. Expt. Sta. Journal Series no. R-10512. I wish to thank Hallie Smith and Claire Jansen-Tingling, Graphics Dept., Office of Academic Technology, Univ. of Florida, for the illustrations.
Nakayama (1964) was the first investigator to simultaneously classify the color of seed, flower, pod, stem, and leaf in $\mathrm{F}_{2}$ segregation materials to find correlations of anthocyanin expression tied to a single locus. The $\mathrm{F}_{2}$ segregation classes from three crosses with 'Blue Butter' (source of his $c^{\text {ui }}$ gene) are described with genotypes [using the gene symbols of Bassett (1994)] at $C$ and $V$ (Table 1 ) as reported and interpreted correctly by Nakayama (1964). Feenstra (1960) described an allele $\left(c^{\mathrm{u}}\right)$ at $C$ that maintains cartridge buff seedcoat color regardless of the genotype at $G, B$, and $V$, i.e., the superscript $\mathrm{u}$ signifies unchangeable expression of cartridge buff seedcoat color. Nakayama (1964) modified the $c^{\mathrm{u}}$ symbol to $c^{\mathrm{ui}}$ for a gene that controls a whole-plant syndrome of effects involving IAE in flowers, pods, stems, and leaves that was unbreakably linked to cartridge buff seedcoat color. The $c^{\text {ui }}$ gene interacts with $V$ to express IAE, whereas $v^{\text {lae }} / v^{\text {lae }}$ greatly diminishes (Table 1 ) and $v / v$ prevents expression of IAE. Nakayama (1964) recognized that $c^{\text {ui }}$ is completely linked to the $N u d$ gene (Lamprecht, 1935; Shaw, 1913) for changes in flower color, as well as the pod, stem, and leaf color syndrome. Thus, the new gene $c^{\text {ui }}$ recessively controls seedcoat color (cartridge buff) but dominantly controls the syndrome of IAE.

Okonkwo and Clayberg (1984) investigated the inheritance of flower and pod color in diallel crosses among seven bean parents with either green pods (three parents) or four types of purple pod expression. They proposed the gene symbol Prp for the locus controlling purple pods and demonstrated the existence of a series of other alleles at Prp, viz., $p r p^{\mathrm{sh}}, p r p^{\mathrm{sh} 2}$, prp $p^{\mathrm{st}}$, and $p r p$. They recognized that the Pur of Lamprecht (1951) is a synonym for $V$, but they did not identify his $R o$ gene with their $\operatorname{Pr} p$ locus due to ambiguities in their data analysis. $\operatorname{Pr} p \operatorname{Vexpresses}$ purple 
pods, and Prp $v$ expresses red (rose) pods (Okonkwo and Clayberg, 1984). Okonkwo and Clayberg (1984) did not cite the work of Nakayama (1964) or the review of Prakken (1970) and were probably unaware of the association of seedcoat color with the syndrome of effects to be expected from Prp (derived from 'Royal Burgundy'). Consequently, they did not classify seedcoat color while recording $\mathrm{F}_{2}$ flower and pod color data.

Bassett (1991) proposed using the bracket convention to more explicitly describe the complex structure of the $C$ gene (region). Bassett (1994) demonstrated that 'Royal Burgundy' carries genotype [ $c^{\mathrm{u}} \mathrm{Prp}^{\mathrm{i}}$ ] $V$ for intense purple flower, cartridge buff seedcoat, and purple color in the pod, stem, and leaf (i.e., the IAE syndrome with unbroken linkage to $c^{\mathrm{u}}$ ). Also, 'Preto 146' carries genotype [C Prp] $V$ for bishops violet flower, black seedcoat, and the absence of IAE syndrome. Bassett (1994) also demonstrated that there is no support for the hypothesis of Okonkwo and Clayberg (1984) that a gene $R o$ interacts with the Prp locus to express anthocyanin in pods. Thus, the "complex $C$ locus" (Prakken, 1974) carries two genes, $C$ for seedcoat color and pattern and Prp for regulation of anthocyanin expression in the flower, pod, stem, and leaf. The gene symbols of all the above investigators for $C$ locus effects on seedcoat color and regulation of anthocyanin expression have been reconciled (Table 2).

Purple pods were observed in materials derived from a test cross with CIAT (Centro Internacional de Agricultura Tropical) accession line G07262. This paper reports the inheritance investigation of the purple pod trait derived from G07262 and the interaction of the genes $T$ and $V$ with IAE syndrome.

\section{Materials and Methods}

The CIAT accession line G07262 is heterogeneous for flower color pattern and has indeterminate plant habit (Type IV). A plant was selected from this accession with the following traits: black seeds with a long, white micropyle stripe (Fig. 1); flowers with 1) broken blue veins on wing petals with a blush of blue color and 2 ) dots and streaks of blue on the banner petal; and green pods. For brevity, this selection will be designated simply as G07262, hereafter. The Florida dry bean breeding line 5-593 has black seeds and bishops violet flowers due to genotype $T P[\mathrm{Cr}] \mathrm{ZJG}$ cean color which is the source of the $c^{\text {ui }}$ gene. ${ }^{z}$

Color of plant organ

\begin{tabular}{ccccc} 
Plant organ & with $V /-$ & with $V /-$ & with $v^{\text {lae }} / v^{\text {lae }}$ & with $v^{\text {lae }} / v^{\text {lae }}$ \\
\hline Flower & Deep violet & Violet & Deep pink & Pink \\
Seedcoat & Colored/buff or buff & Colored & Colored $/$ buff or buff & Colored \\
Pod & Purple & Green & Reddish brown tinged & Green \\
Leaf & Purple & Green & Reddish brown tinged & Green \\
\hline \hline
\end{tabular}

The gene symbols of Bassett (1994) were used for genes at the complex $C$ region, e.g., the $c^{\text {ui }}$ gene of Nakayama ${ }^{y}$ Colored/buff $=$ heterozygous marbling of seedcoats, viz., colored and cartridge buff. The term "colored" indicates any of a large number of seedcoat colors depending on genes for seedcoat color not specified. Buff = cartridge buff

Table 2. A reconciliation of gene symbols used by investigators of the inheritance of anthocyanin expression in pods [and associated intensified anthocyanin expression (IAE) syndrome] of common bean and proposed new symbols is presented.

\begin{tabular}{|c|c|c|c|c|c|c|}
\hline \multirow[b]{3}{*}{ Source variety } & \multicolumn{2}{|c|}{ Phenotypes $^{2}$} & \multirow[b]{2}{*}{ V } & \multicolumn{2}{|c|}{ Gene symbols for $C$} & \multirow[b]{3}{*}{ Literature citations } \\
\hline & Flow- & & & Proposed by & Original & \\
\hline & $\operatorname{ers}^{y}$ & Pods $^{x}$ & locus & Bassett $^{\mathrm{w}}$ & symbols & \\
\hline \multirow[t]{2}{*}{ Blue Butter } & DP & MP & $V$ & {$\left[c^{\mathrm{u}} \operatorname{Prp}^{\mathrm{i}}\right]$} & Nud & Lamprecht, 1951 \\
\hline & & & & & $c^{\mathrm{ui}}$ & Nakayama, 1964 \\
\hline Royal Burgundy & DP & MP & $V$ & {$\left[c^{\mathrm{u}} \operatorname{Prp}^{\mathrm{i}}\right]$} & $\operatorname{Prp}$ & Okonkwo and Clayberg, 1984 \\
\hline \multirow[t]{2}{*}{ Preto-146 } & LP & DP & $V$ & {$[C$ Prp $]$} & Ro & Lam-Sanchez and Vieira, 1964 \\
\hline & & & & & prp ${ }^{\mathrm{sh} 2}$ & Okonkwo and Clayberg, 1984 \\
\hline \multirow[t]{2}{*}{ V0903 (PI 527818) } & LP & $\mathrm{SH}$ & $V$ & {$\left[c^{\mathrm{u}} p r p^{\mathrm{sh}}\right]$} & Ro & Lamprecht, 1951 \\
\hline & & & & & $p r p^{\text {sh }}$ & Okonkwo and Clayberg, 1984 \\
\hline V0747, Contender & LP & ST & $V$ & {$\left[c^{\mathrm{u}} p r p^{\mathrm{st}}\right]$} & $p r p^{\mathrm{st}}$ & Okonkwo and Clayberg, 1984 \\
\hline \multirow[t]{2}{*}{ Montaigao-Fosco-1 } & $\mathrm{W}$ & $\mathrm{G}$ & $v$ & {$[$ C prp $]$} & ro & Lam-Sanchez and Vieira, 1964 \\
\hline & & & & & prp & Okonkwo and Clayberg, 1984 \\
\hline
\end{tabular}

The terms for description of flowers and pods are those of Okonkwo and Clayberg (1984, Table 1).

Corolla wings: DP = dark purple (intense bishops violet), LP = light purple (bishops violet), $\mathrm{W}=\mathrm{white}$.

Color of immature pods just prior to ripening: $\mathrm{DP}=$ dark purple, $\mathrm{MP}=$ medium purple, $\mathrm{SH}=$ green with purple , and first applied to pod color genes at $C$ by Bassett (1994).

$B V R k$ (Bassett, 2003). Line 5-593 has been used as the recurrent parent in the development of many genetic stocks, in which (usually) recessive marker genes have been backcrossed (usually to $\mathrm{BC}_{3}$ ) to 5-593 with selection against all other marker gene traits. The development of partly colored genetic stocks $t z$ virgarcus $\mathrm{BC}_{2} 5-593$ and $t z$ bip bipunctata $\mathrm{BC}_{1}$ 5-593 with white flowers (due to $t$ ) was previously described (Bassett, 1996). Similarly, the genetic stock $c^{\mathrm{u}} b v r k^{\mathrm{d}} \mathrm{BC}_{2}$ 5-593 with white flowers (with red veins in the wing petals) and garnet brown seedcoats (dark red kidney class) was previously described (Bassett and Miklas, 2003). The genetic stock $v$ BC 2 5-593 with mineral brown seedcoats and white flowers was developed in the usual way (Bassett, 1998a).

The crosses 5-593 x G07262, G07262 x tz bip bipunctata $\mathrm{BC}_{1}$ 

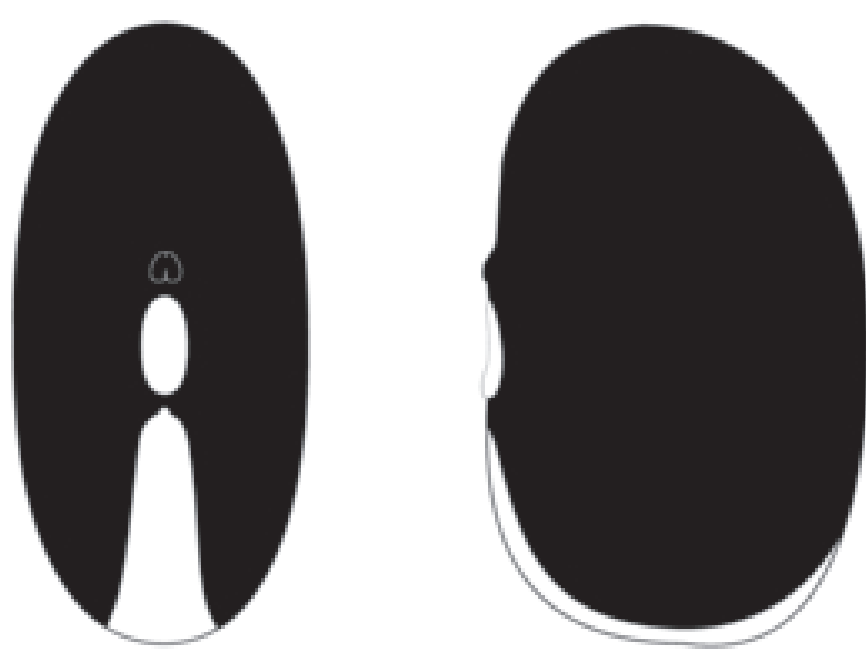

Fig. 1. A ventral view (left seed) and a side view (right seed) of a long, white micropyle stripe in common bean expressed by genotype $t p^{\text {mic }}$.

5-593, and G07262 x v BC 2 5-593 were made in the Fall 1993 greenhouse. Data were recorded for the color and pattern of flowers, seedcoats and pods of $F_{1}$ progeny of all three crosses grown in the greenhouse. Data were recorded in field grown $\mathrm{F}_{2}$ progeny for IAE syndrome and flower color segregation for G07262 x v $\mathrm{BC}_{2}$ 5-593 in Spring 1994. Data were recorded in field grown $\mathrm{F}_{2}$ progeny for flower color and seedcoat pattern segregation for G07262 x $t$ z bip bipunctata BC $_{1}$ 5-593 in Spring 1994.

From the cross $\mathrm{G} 07262 \times v \mathrm{BC}_{2} 5-593$, a true breeding selection was made in $\mathrm{F}_{4}$ progeny for white flowers with banner petals having a brilliant red exterior side and determinate habit. This selection was designated " $F_{4}$ red banner back" and lacked any other plant organs with IAE. In Fall 2000, the cross $\mathrm{F}_{4}$ red banner back $\times$ 5-593 was made, and the $\mathrm{F}_{2}$ was grown in the field in Spring 2001. Data were recorded for color and pattern in flowers, seedcoats, and other plant organs in the $F_{1}$ and $F_{2}$ progeny.

From the cross $5-593 \times$ G07262, a true breeding selection was made for white flowers with blue veins on the wing petals and determinate habit. This selection was designated " $F_{3}$ white flower/blue vein." In Fall 1994, the cross $\mathrm{F}_{3}$ white flower/blue vein $\mathrm{x} t z$ virgarcus $\mathrm{BC}_{2}$ 5-593 was made, and a true breeding $\mathrm{F}_{4}$ selection was made for white flowers with blue veins in the wing petals. This selection was designated " $\mathrm{F}_{4}$ white flowers/blue vein $\mathrm{BC}_{1}$ 5-593." In Fall 2000, a test cross was made to determine whether the gene for IAE syndrome from G07262 is allelic with $C$. This cross was: $\mathrm{F}_{4}$ white flowers/blue vein $\mathrm{BC}_{1} 5-593 \times c^{\text {u }} b$ $v r k^{\mathrm{d}} \mathrm{BC}_{1} 5-593$, and serious problems with sterility (due to heat sensitivity) were observed in the $F_{2}$ progeny in Spring 2001. A selection was made in $\mathrm{F}_{2}$ for a two-colored seedcoat: black ventral side and garnet brown [the color of dark red kidney (DRK) beans] dorsal side. This selection was true breeding in $\mathrm{F}_{3}$ and was designated " $\mathrm{F}_{3}$ black ventral/DRK dorsal $\mathrm{BC}_{1}$ 5-593." In Fall 2002, the cross $\mathrm{F}_{3}$ black ventral/DRK dorsal $\mathrm{BC}_{1}$ 5-593 x 5-593 was made, and the $\mathrm{F}_{2}$ was grown in the field in Spring 2003. For each backcross cycle, data were recorded for color and pattern in flowers and seedcoats of the $F_{1}$ and $F_{2}$ progeny.

\section{Results and Discussion}

The main genetic hypothesis of this paper is that G07262 carries a gene, $\operatorname{Pr} p^{\mathrm{i}}-2$, that is independent of $C$ and expresses IAE syndrome. To make this paper easier to follow, this genetic hypothesis will be indicated for all parental materials throughout the presentation below.

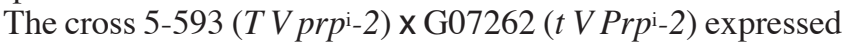
intense purple flowers, purple pods, and IAE syndrome in $\mathrm{F}_{1}(T / t$

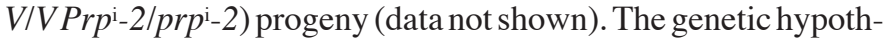
esis is that the Prpi-2 gene in G07262 is exposed (expressed) in $\mathrm{F}_{1}$ due to removal (due to $T / t$ ) of the epistatic suppression by $t / t$ in G07262. Thus, G07262 carries $\operatorname{Prp}^{\mathrm{i}-2}$ cryptically due to $t / t$. The cross G07262 ( $t V$ Prp $\left.^{\mathrm{i}-2}\right) \times v\left(\right.$ p prp $\left.^{\mathrm{i}-2}\right) \mathrm{BC}_{2}$ 5-593 also expressed intense purple flowers, purple pods, and IAE syndrome in

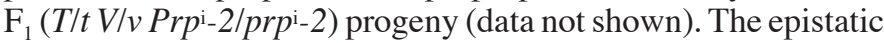
suppression of IAE syndrome by $t / t$ in G07262 was released in $\mathrm{F}_{1}$ progeny due to $T / t$. The segregation for IAE syndrome in $\mathrm{F}_{2}$ fit the expected trigenic ratio of 27 IAE syndrome plants to 37 plants without IAE syndrome and either purple (bishops violet) or white flowers (Table 3$)$. The data had a better fit $(P=0.38)$ to a 9:7 ratio (Table 3 ), but the observed phenotypic segregation cannot be reconciled with segregation for $p r p^{\mathrm{i}}-2 / p r p^{\mathrm{i}}-2$ and only one other gene ( $t$ or $v$ ), as demonstrated below. Thus, IAE syndrome expression with $\operatorname{Prp}^{\mathrm{i}}-2 /$ - can be suppressed by either $t / t$ or $v / v$. The data from the two crosses described above support the hypothesis of a single dominant gene for IAE syndrome carried by G07262 but masked by $t / t$.

The cross G07262 ( $t p^{\text {mic }} Z$ Bip V Prp $\left.{ }^{\mathrm{i}-2}\right) \times t z$ bip (PV prp $^{\mathrm{i}-}$ 2) bipunctata $\mathrm{BC}_{1} 5-593$ produced $\mathrm{F}_{1}$ progeny ( $t / t$ Bip/bip $Z / z$

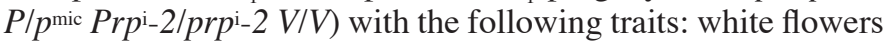
with blue veins on the wing petals, partly colored seedcoats with the expansa pattern, and absence of IAE syndrome (data not shown). Thus, the $\mathrm{F}_{1}$ had the same flower color and pattern as the G07262 parent. The expression of white flowers and partly colored seedcoats is known to be due to the gene $t$ (Prakken, 1970, 1972). Therefore, the data support the hypothesis that G07262 has genotype $t$. The observed segregation in $\mathrm{F}_{2}$ progeny demonstrated that segregation at the $P$ locus was independent of segregation for blue veins in the wing petals, but all flowers were otherwise white (Table 4). Also, all plants with seedcoats having a white micropyle stripe ( $\left.p^{\text {mic }}\right)$ had the characteristic long stripe (Fig. 1) expressed by the genetic interaction of $t p^{\text {mic }}$ (Bassett, 1998b); and a portion of those ( $\left.t p^{\text {mic }}\right)$ plants expressed the interaction of $z$ with $t p^{\text {mic }}$ (Fig. 2), a further restriction of the colored zone (Table 4). Thus, the hypothesis that G07262 carries $t$ was confirmed. The observed segregation in $\mathrm{F}_{2}$ progeny also demonstrated that a dominant gene controls the expression of blue veins (Table 4). A preliminary hypothesis is that the gene controlling blue vein expression is the same gene, viz., $\operatorname{Prp}^{\mathrm{i}}-2$,

Table 3. Segregation in common bean for intensified anthocyanin expression (IAE) syndrome and flower color in the $\mathrm{F}_{2}$ from the cross G07262 ( $t$ V Prp $p^{\mathrm{i}-2)} \times v^{2}\left(\right.$ T prp ${ }^{\mathrm{i}-2)} \mathrm{BC}_{2}$ 5-593.

$\operatorname{Prp}-2 /-$ or $p r p^{\mathrm{i}}-2 / p r p^{\mathrm{i}}-2$

$\operatorname{Prp}-2 /-T /-V /-\quad$ with $T /-v / v, t / t V /-$, or $t / t v / v$;

Presence of $\quad$ or $p r p^{\mathrm{i}}-2 / p r p^{\mathrm{i}}-2 \mathrm{~T} / \mathrm{V} / \mathrm{-}$

IAES, intense Absence of IAES, purple ${ }^{\mathrm{z}}$ or $\quad \chi^{2}$

purple flower

white flower $^{2}$

$27: 37^{x}$ $P$

24

24

1.201

0.27

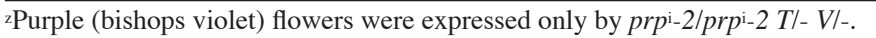
y Segregation for blue veins on wing petals was observed. ${ }^{x} \chi^{2}(9: 7)=0.762, P=0.38$. 
Table 4. Segregation observed in common bean for blue flower veins (in wing petals) and seedcoat patterns in the $\mathrm{F}_{2}$ from the cross $\mathrm{G} 07262$ ( $t$ Z Bip p p ${ }^{\text {mic }} V$ Prp $\left.{ }^{\mathrm{i}}-2\right) \times t z$ bip $\left(P V\right.$ prp $\left.{ }^{\mathrm{i}}-2\right)$ bipunctata $\mathrm{BC}_{1}$ $5-593 .^{z}$

\begin{tabular}{|c|c|}
\hline$P /-$ & $p^{\mathrm{mic}} / p^{\mathrm{mic}}$ \\
\hline \multirow[t]{2}{*}{$p r p^{\mathrm{i}}-2 / p r p^{\mathrm{i}}-2$} & $p r p^{\mathrm{i}}-2 / p r p^{\mathrm{i}}-2$ \\
\hline & Long white micropyle stripe \\
\hline Self- or partly colored seedcoat, ${ }^{y}$ & seedcoat, ${ }^{x}$ \\
\hline white flower & white flower \\
\hline
\end{tabular}

\begin{tabular}{cccccc} 
With & Without & With & Without & $\chi^{2}$ & \\
blue veins & blue veins & blue veins & blue veins & $9: 3: 3: 1$ & $P$ \\
\hline 57 & 17 & 12 & 0 & $8.016^{\mathrm{w}}$ & 0.046
\end{tabular}

${ }^{2}$ The seedcoats, whether self-colored or partly colored, were black $(B V)$ for all plants.

ySeven plants had black self-colored seedcoats; and partly colored (always black) patterns included expansa, virgarcus, and bipunctata.

xAll plants had black seedcoats with the long micropyle stripe of $t p^{\text {mic }}$ (Fig. 1), which was enlarged by (partly colored) interactions with $z$ (Fig. 2) in some plants (Bassett, 1998b).

" $\chi^{2}$ component for $p^{\text {mic }} p r p^{i}-2$ was 5.375 .
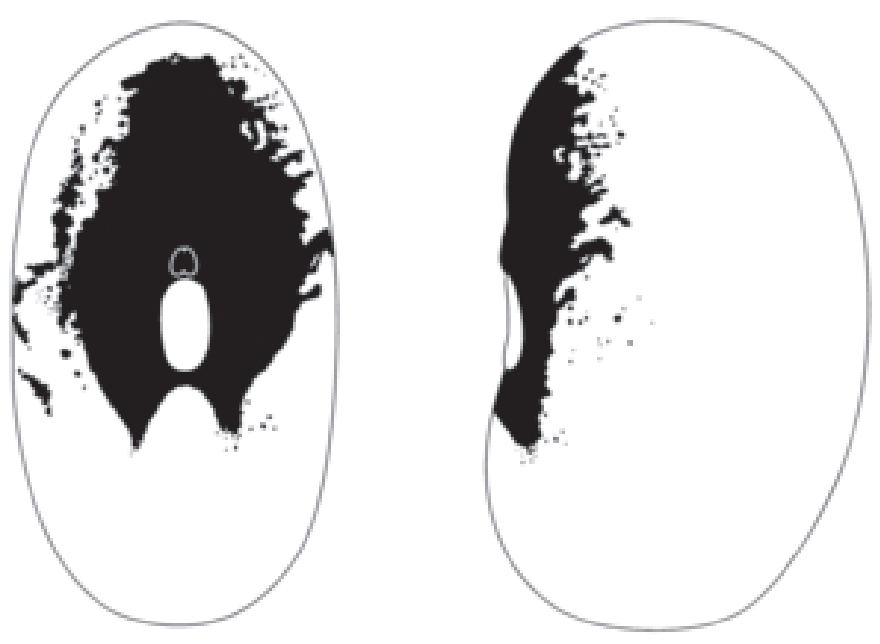

Fig. 2. A ventral view (left seed) and a side view (right seed) of the interaction of the partly colored seedcoat pattern in common bean expressed by the genotype $t z p^{\text {mic. }}$.

from G07262 that will be further demonstrated below to control the IAE syndrome. However, a full investigation of the inheritance of vein color in wing petals is beyond the scope of this paper and will not be pursued further. The observed segregation in $\mathrm{F}_{2}$ also confirms the hypothesis that $\mathrm{G} 07262$ carries genotype $t p^{\text {mic }} B V$, expressing black seedcoats with a long, white micropyle stripe (Table 4). There was no IAE syndrome observed in either $F_{1}$ or $\mathrm{F}_{2}$ (data not shown). Thus, genotype $t / t$ prevents the expression of IAE syndrome by $\operatorname{Prp}^{\mathrm{i}-2}$, and genotype $T /-\operatorname{Pr}^{i}-2 /$ - is required for IAE syndrome expression.

The cross $\mathrm{F}_{4}$ red banner back ( $v$ Prpi-2) x 5-593 (V prpi-2) produced $\mathrm{F}_{1}(V / v$ Prpi-2/prpi-2) progeny expressing black seedcoats and IAE syndrome, including intense bishops violet flowers and purple pods (data not shown). For a full description of the syndrome, see Table 1 . The four phenotypic classes observed in the $F_{2}$ fit a 9:3:3:1 segregation ratio (Table 5), and the middle two classes correspond to the parental flower phenotypes. The segregation class with a $9 / 16$ frequency expresses the same IAE syndrome as the $c^{\text {ui }}$ gene (see Table 1), which now has the gene symbol $\left[c^{\mathrm{u}} \operatorname{Prp}^{\mathrm{i}}\right]$. The gene carried by G07262 for IAE differs from the gene carried by 'Blue Butter' and 'Rogyal Burgundy' because the former has no linked gene effect for cartridge buff seedcoats. The question remains whether the IAE gene in G07262 is a new allele at the 'complex $C$ locus' or an independent gene.

The cross $\mathrm{F}_{3}$ black ventral/DRK dorsal $\left(c^{\mathrm{u}} r k^{\mathrm{d}} P r p^{\mathrm{i}}-2\right) \times$ 5-593 $(C R k$ prpi-2) produced $\mathrm{F}_{1}$ progeny $\left(C / c^{\mathrm{u}} R k /\right.$ $\left.r k^{\mathrm{d}} P r p^{\mathrm{i}}-2 / p r p^{\mathrm{i}}-2\right)$ with IAE syndrome (e.g., intense bishops violet flowers and purple pods) and black seedcoats (data not shown). The $\mathrm{F}_{2}$ progeny segregated for six phenotypic classes that fit a 36:9:3:12:3:1 segregation ratio (Table 6). The IAE syndrome expressed by the first three classes is attributed to the Prpi-2 gene. The fourth through the sixth classes did not express IAE syndrome, for which the genetic hypothesis is $p r p^{\mathrm{i}-2 / p r p^{\mathrm{i}}-2}$ (Table 6). When IAE syndrome was expressed (Prpi-2/-), there were two types of two-colored seedcoats observed in separate phenotypic classes: 1) seedcoats with a purple ventral area (margo (Fig. 3) or less extensive zone) and a cartridge buff dorsal color (remainder) and 2) seedcoats with a black ventral area (margo or more extensive zone) and a garnet brown dorsal color (same as the dark red kidney bean class). The hypothetical genotypes (at $C$ and $R k$ ) of the two classes were $c^{\mathrm{u}} R k /-$ and $c^{\mathrm{u}} r k^{\mathrm{d}}$, respectively. When IAE syndrome was not expressed ( $\left.p r p^{\mathrm{i}}-2 / p r p^{\mathrm{i}}-2\right)$, the fifth and sixth classes in Table 6 expressed either cartridge buff seedcoats $\left(c^{\mathrm{u}} R k /-\right)$ or garnet brown seedcoats $\left(c^{\mathrm{u}} r k^{\mathrm{d}}\right)$, respectively. Thus, the two-colored seedcoat classes were the expression of a trigenic interaction never previously reported. The first and fourth phenotypic classes have black seedcoats due to $C /-$, which, with $V$, covers up the expression of $r k^{\mathrm{d}}$. Thus, the segregation at $\operatorname{Prp}^{\mathrm{i}}-2$ is independent of segregation at $C$. Therefore, the gene for IAE syndrome from G07262 must have a locus independent of $C$. The gene symbol Prpi-2 is formally proposed for the new gene, to distinguish it from $\left[c^{\mathrm{u}} \operatorname{Pr} p^{\mathrm{i}}\right]$. The question remains whether $\operatorname{Pr} p^{\mathrm{i}}-2$ is 1) the result of de novo development of a gene similar to $\operatorname{Prp}^{\mathrm{i}}$ or 2) the result of ectopic gene duplication. Further research is needed to determine the origin of $\operatorname{Prp}^{\mathrm{i}}-2$.

\section{Literature Cited}

Bassett, M.J. 1991. A revised linkage map of common bean. HortScience 26:834-836.

Bassett, M.J. 1994. Tight linkage of purple pod character and the complex $C$ locus in common bean. J. Hered. 85:288-290.

Bassett, M.J. 1996. Inheritance of the partly colored seedcoat pattern, bipunctata, in common bean. J. Amer. Soc. Hort. Sci. 121:1032-1034.

Bassett, M.J. 1998a. List of seed coat genetic tester stocks in the 5-593 genetic background. Annu. Rpt. Bean Improvement Coop. 41:125-126.

Bassett, M.J. 1998b. A third recessive allele, $s p^{\text {mic }}$, for seedcoat pattern at the Stp locus in common bean. J. Amer. Soc. Hort. Sci 123:404-406. 
Table 5. Segregation observed in common bean for flower and seedcoat color and intensified anthocyanin expression (IAE) syndrome in $\mathrm{F}_{2}$ progeny from the cross $\mathrm{F}_{4}$ red banner back $\left(\right.$ Prp $\left.^{\mathrm{i}-2} v\right) \mathrm{x}$ 5-593 (prpi-2 V).

\begin{tabular}{|c|c|c|c|c|c|}
\hline \multicolumn{6}{|c|}{ White flower with } \\
\hline Intense bishops & Bishops or cobalt & red banner back, ${ }^{\mathrm{z}}$ & & & \\
\hline violet flower, black & violet flower, black & M.B. seedcoat ${ }^{\mathrm{y}}$, no & White flower, M.B. & & \\
\hline seedcoat, IAES & seedcoat, no IAES & IAES & seedcoat $^{\mathrm{y}}$, no IEAS & $\chi^{2}$ & \\
\hline Prpi-2/- V/- & $p r p^{\mathrm{i}}-2 / p r p^{\mathrm{i}}-2 \mathrm{~V} /-$ & $\operatorname{Prp}-2 /-v / v$ & $p r p^{\mathrm{i}}-2 / p r p^{\mathrm{i}}-2 v / v$ & $9: 3: 3: 1$ & $P$ \\
\hline 196 & 80 & 65 & 21 & 2.690 & 0.44 \\
\hline
\end{tabular}

zThe inner side of the banner petal is nearly white (very pale pink), but the outer side is a brilliant red.

y.B. = mineral brown (due to $G B v$ ).

Table 6. Segregation observed in common bean for intensified anthocyanin expression (IAE) syndrome and seedcoat color and pattern in the $\mathrm{F}_{2}$ progeny from the cross ' $\mathrm{F}_{3}$ black ventral/DRK dorsal

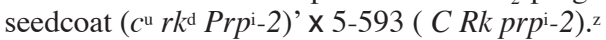

\begin{tabular}{|c|c|c|c|c|c|c|c|}
\hline $\operatorname{Prp}-2 /-$ & $\operatorname{Prp}{ }^{\mathrm{i}}-2 /-$ & $\operatorname{Prp} p^{\mathrm{i}}-2 /-$ & $p r p^{\mathrm{i}}-2 / p r p^{\mathrm{i}}-2$ & $p r p-2 / p r p p^{\mathrm{i}}-2$ & $p r p^{\mathrm{i}}-2 / p r p^{\mathrm{i}}-2$ & & \\
\hline $\mathrm{C} /-$ & $c^{\mathrm{u} /} / c^{\mathrm{u}}$ & $c^{\mathrm{u} / c^{\mathrm{u}}}$ & $\mathrm{C} /-$ & $c^{\mathrm{u} /} / c^{\mathrm{u}}$ & $c^{\mathrm{u} / c^{\mathrm{u}}}$ & & \\
\hline$-/-$ & $R k /-$ & $r k^{\mathrm{d} / r k^{\mathrm{d}}}$ & $-/-$ & $R k /-$ & $r k^{\mathrm{d} / r k^{\mathrm{d}}}$ & & \\
\hline \multirow[t]{2}{*}{ IAES, } & IAES, & IAES, & No IAES & No IAES & No IAES & & \\
\hline & Purple & & & & Garnet & & \\
\hline Black & $\operatorname{margo} / c^{\mathrm{u}}$ & Black/DRK & Black & Cartridge & brown & $\chi^{2}$ & \\
\hline seedcoat & seedcoat $^{y}$ & seedcoat $^{x}$ & seedcoat & buff seedcoat & seedcoat & $36: 9: 3: 12: 3: 1$ & $P$ \\
\hline
\end{tabular}

$\begin{array}{llllllll}77 & 13 & 8 & 17 & 6 & 2 & 4.422 & 0.49\end{array}$

IAE is described in Table 1. All $\mathrm{F}_{2}$ plants had either intense violet (Prpi-2/-) or bishops violet (prpi-2/prpi-2) flowers. Thus, no segregation for $t / t$ or $v / v$ was observed.

y Purple margo/cu seedcoats have a purple ventral zone (margo (Fig. 3) or more extensive) and a cartridge buff remainder.

xBlack/DRK seedcoats have a black ventral side and the garnet brown of dark red kidney class beans on the dorsal side.

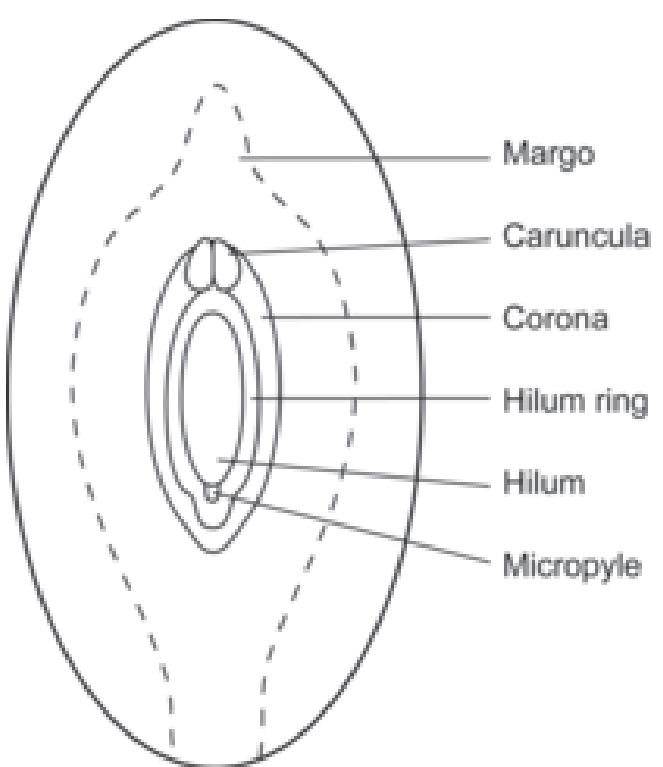

Fig. 3. Elements of seedcoat anatomy in a ventral view of a common bean seed.
Bassett, M.J. 2003. The seed coat color genotype of 5-593, the recurrent parent of many genetic stocks of common bean maintained as PI lines at Pullman, WA. Annu. Rpt. Bean Improvement Coop. 46:37-38.

Bassett, M.J. and P.N. Miklas. 2003. New alleles, $r k^{\mathrm{cd}}$ and $r k^{\mathrm{p}}$, at the red kidney locus for seedcoat in common bean. J. Amer. Soc. Hort. Sci. 128:552-558.

Feenstra, W.J. 1960. Biochemical aspects of seedcoat colour inheritance in Phaseolus vulgaris L. Mededelingen Landbouwhogeschool, Wageningen 60:1-53.

Lamprecht, H. 1935. Zur Genetik von Phaseolus vulgaris. XII. Über die Vererbung der Blüten- und Stammfarbe. Hereditas 21:129-166.

Lamprecht, H. 1951. Über die Vererbung der roten Hülsenfarbe bei Phaseolus vulgaris. Agri Hortique Genetca 9:84-87.

Lam-Sanchez, A. and C. Vieira. 1964. Hereditariedade da côr das vagens de Phaseolus vulgaris L. Revista Ceres 12:106-118.

Nakayama, R. 1964. Genetical studies on kidney beans (Phaseolus vulgaris). VII. A modifier of flower color and its relation to $c^{\mathrm{u}}$ gene. Bul. Fac. Agr. Hirosaki Univ. 10:1-13.

Okonkwo, C.A. and C.D. Clayberg. 1984. Genetics of flower and pod color in Phaseolus vulgaris. J. Hered. 75:440-444.

Prakken, R. 1970. Inheritance of colours in Phaseolus vulgaris L. II. A critical review. Mededelingen Landbouwhogeschool Wageningen, 70-23:1-38.

Prakken, R. 1972. Inheritance of colours in Phaseolus vulgaris L. III. On genes for red seedcoat colour and a general synthesis. Mededelingen Landbouwhoge school Wageningen, 72-29:1-82.

Prakken, R. 1974. Inheritance of colours in Phaseolus vulgaris L. IV. Recombination within the 'complex locus $C$ '. Mededelingen Landbouwhogeschool Wageningen, 74-24:1-36.

Shaw, J.K. 1913. The inheritance of blossom color in beans. Mass. Agr. Expt. Sta. 25th Annu. Rpt. 